\title{
SEDIMENTARY MINERALOGY AND ORGANIC GEOCHEMISTRY OF THE MIOCENE ARGILLACEOUS ROCKS IN SOUTHWEST OF YAITA CITY, TOCHIGI, JAPAN
}

\author{
Korchi Aoyagi, Shuji Kudo and Tadashi Asakawa* \\ Central Technical Laboratory, Japan Petroleum Explovation Co. Ltd., 3190-1 Hane, \\ Hamura-machi, Nishitama-gun, Tokyo, Japan
}

\begin{abstract}
Mineral assemblage of the argillaceous rocks of the Miocene Takashio-Tamada formations in southwest of Yaita City, Tochigi, Japan, is identified as the detrital montmorillonite and authigenic mordenite-clinoptilolite-cristobalite zone. This mineral assemblage indicates that the argillaceous rocks of these formations in the studied area have been subjected to temperatures between 56 and $69^{\circ} \mathrm{C}$ in the geologic past and consequently the paleogeothermal gradient is estimated to be approximately $2.2^{\circ} \mathrm{C} / 100 \mathrm{~m}$ and the stratigraphic deficiency after the deposition of Tamada formation is calculated to be about $1800 \mathrm{~m}$.

Hydrocarbons/organic carbon ratio indicates that the hydrocarbons in the argillaceous rocks of the area have not matured yet. Also, the quantity of organic matter is decidedly low.

It is expected that the primary migration of carrier water of oil in the Miocene of the area would occur when the burial depth of the sediments reached between about 1100 and $2700 \mathrm{~m}$. The possibility of the presence of oil pools may be poor because the generation of petroleum hydrocarbons during the stage of primary migration is considered to have been low. Natural gas pools, however, may be expected to exist in the surrounding area.
\end{abstract}

\section{INTRODUCTION}

The Tamada-Takashio hills area southwest of Yaita City, Tochigi Prefecture, Japan, is well known for the only oil shows found in the northern Kanto mountains (Uchio, 1950). The area is located about 20 $\mathrm{km}$ north of Utsunomiya City (see Fig. 1) and is made up of gentle hills about $250 \mathrm{~m}$ above sea level. The writers studied the geology of the Miocene in the area and collected many sedimentary rocks. We have identified the mineral composition of argillaceous rocks by X-ray diffractometer and analyzed the organic components in these samples.

In the present paper, we will explain the geology of the area briefly, estimate the paleogeothermal gradient and the stratigraphic deficiency through succession in the area from a sedimentary mineralogical points of view, and report the maturity and quantity of organic matter in these rocks. Afterwards, we will examine the vertical change of absolute porosity in argillaceous rocks of the area, and discuss the possibility of the presence of hydrocarbon pools in the area based on theories of generation and primary migration of petroleum.

\section{Outline of Geology}

The Miocene of the investigated area overlies a basement of quartz porphyry of

* Present Address: Technology Research Centre, Japan National Oil Corp., Tokyo, Japan (Manuscript received January 10, 1979) 


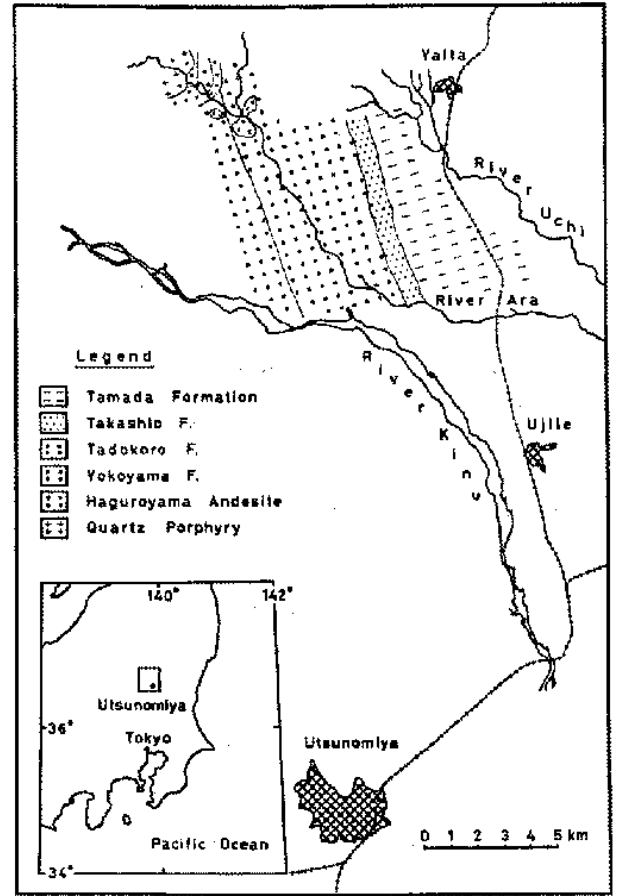

Fig. 1 Index and geological maps of the studied area.

unknown age and is composed of the Yokoyama, Tadokoro, Haguroyama andesite complexes, Takashio, and Tamada formations. Geological map of the basin is shown in Fig. 1. The strike of each formation is north-south in general, and the dip is gently west from 5 to $10^{\circ}$. In the eastern part of the area, the structure of the Miocene is monoclinal and faults are not common. In the western part, however, the structure is complicated by the intrusion of Haguroyama andesite complexes and by many faults. Generalized columnar section showing the thickness, location of collected samples and foraminifera in each formation of the Miocene are shown in Fig. 2.

In general, the Yokoyama formation is composed of massive dark-grey pumiceous tuff and tuff breecia. The middle part of the formation consists of alternations of dark-grey tuffaceous pebbly sandstone con-

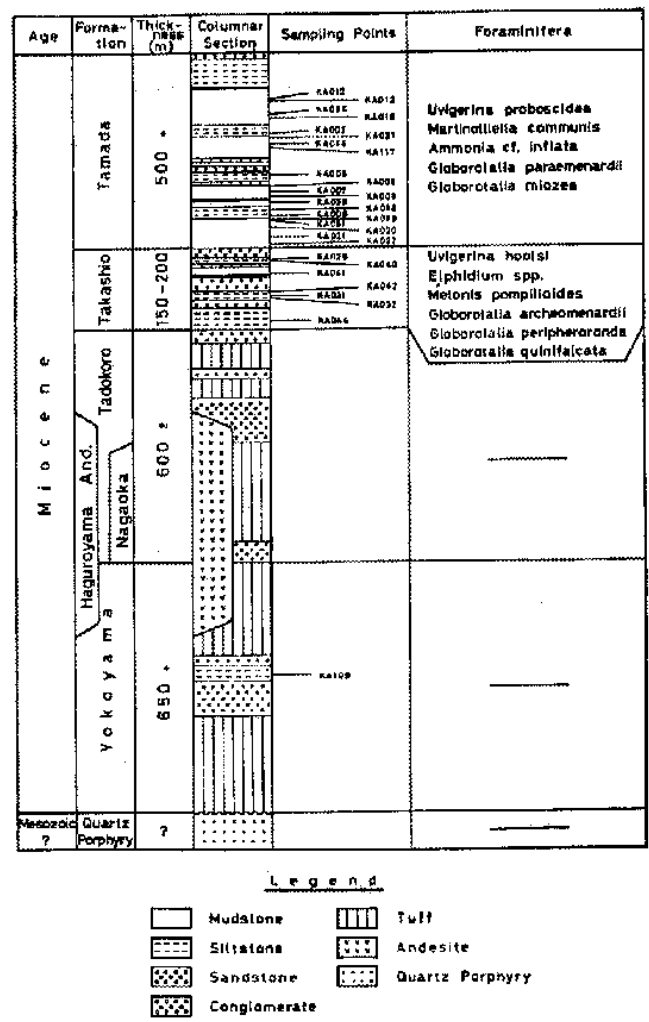

Fig. 2 Generalized columnar section showing the thickness, location of samples and foraminiferal assemblages of the Miocene in the area.

taining molluscan fossils, bluish-grey tuffaceous coarse sandstone, dark grey tuffaceous siltstone, and dark-grey tuffaceous mudstone. Foraminifera are absent, but sedimentary facies indicate that the depositional environment would have been innerneritic to littoral.

The type locality of the Tadokoro formation is in the vicinity of Tadokoro village along the Ara River. The formation is generally composed of green pumiceous tuff and pebbly tuff resembling the socalled Ohya-ishi, and sometimes contains conglomerate, pebbly sandstone and tuffaceous sandstone. Plant fragments are abundant in the upper part of the formation. 
The lower part constitutes the Nagaoka member and its base is composed of tuffaceous conglomerate. The Nagaoka member and the Yokoyama formation are intruded by the Haguroyama andesite complexes composed mainly of two-pyroxene andesite. As foraminifera have not been found to date, sedimentary facies are taken to indicate that the depositional environment would have been inner to outer neritic.

The Takashio formation has its type locality near the Takashio village in the northern part of the district. The formation consists of alternations of white-grey pumiceous tuff, light-grey tuffaceous fine sandstone, and dark-grey siltstone. Therefore, it resembles the Idozawa formation in the vicinity of Tomioka city in Gunma Prefecture. Generally, the siltstones are poorly sorted and contain scattered sand beds or laminae. Shell beds are common in the upper part of the formation, and fragments of plants are abundant in the lower part. From the foraminiferal assemblage, it is assumed that the depositional environment was bathyal and was affected by warm currents.

The type locality of the Tamada formation is near the Tamada village in the centre of the studied area. Generally, the lithofacies are similar to the so-called hard black shale in the northwestern area of Honshu, Japan. However, it is more silty and contains much biotite, and thus it closely resembles the Yoshii formation in the western part of Takasaki city, Gunma Prefecture. The lower part of the formation has shell beds. Several white-grey pumiceous tuffs can be found in the lower part of the formation and can be easily traced laterally through the whole area. The foraminiferal assemblage indicates a bathyal environment affected by warm currents.

\section{Mineral Composition AND ESTI- MAtion OF PALEOGEOTHERMal GradienT}

The mineral composition of the Miocene argillaceous rocks in the area was quantitatively analyzed by an X-ray diffractometer. The results of analysis are shown in Fig. 3. This figure indicates that clay mineral facies (Aoyagi et al, 1975) in the argillaceous rocks of the Takashio and Tamada formations is identified as the Ia2 type (montmorillonite-illite-scarce chlorite zone), zeolite facies as the mordeniteclinoptilolite zone, and silica mineral facies as the cristobalite zone. Calcite is generally common, and gypsum and tremolite are also conspicuously present. Montmorillonite-illite mixed-layer mineral is found in sample KAO51. However, mineral com-



Fig. 3 Mineral composition of argillaceous rocks in the area. Mon : montmorillonite, Mix: mixed-layer mineral of montmorillonite and illite, Ill: illite, Chl: chlorite, Cri : low-cristobalite, Qtz: low-quartz, Pla: palgioclase, Cli: clinoptilolite, Mor: mordenite, Gyp: gypsum, Cal: calcite, Dol: dolomite, Sid:siderite, and Tre: tremolite. 
position of the argillaceous rocks of the Yokoyama and Tadokoro formations is not clear as the number of analyzed samples is limited.

As was discussed in detail by Aoyagi and Kazama (1978), the most important factors affecting the diagenetic transformation of minerals in argillaceous rocks will be physical parameters such as overburden pressure, geothermal temperature and geological reaction time, in addition to chemical parameters such as $\mathrm{pH}$, Eh and ionic composition of the fluid in sediment. They established the following relations between the transformation of authigenic minerals in Cretaceous and Tertiary argillaceous rocks and geothermal temperatures and overburden pressures at the deeply drilled wells in Japan. In clay minerals, a pressure of $900 \mathrm{~kg} / \mathrm{cm}^{2}$ and a temperature of $104^{\circ} \mathrm{C}$ are necessary for the transformation from montmorillonite to montmorillonite-illite mixed-layer mineral, and 920 $\mathrm{kg} / \mathrm{cm}^{2}$ and $137^{\circ} \mathrm{C}$ for mixed-layer mineral to illite. In zeolites, $330 \mathrm{~kg} / \mathrm{cm}^{2}$ and $56^{\circ} \mathrm{C}$ are required for the transformation from volcanic glass to clinoptilolite, $860 \mathrm{~kg} / \mathrm{cm}^{2}$ and $116^{\circ} \mathrm{C}$ for clinoptilolite to analcite and/or heulandite, and $930 \mathrm{~kg} / \mathrm{cm}^{2}$ and $138^{\circ} \mathrm{C}$ for analcite and/or heulandite to laumontite and/or albite. In silica minerals, 250 $\mathrm{kg} / \mathrm{cm}^{2}$ and $45^{\circ} \mathrm{C}$ are necessary for the transformation from amorphous silica to low-cristobalite, and $660 \mathrm{~kg} / \mathrm{cm}^{2}$ and $69^{\circ} \mathrm{C}$ for low-cristobalite to low-quartz. Geological reaction time necessary for these transformations ranges between $1 \mathrm{~m} . \mathrm{y}$. and $130 \mathrm{~m} . \mathrm{y}$.

The mineral assemblage of the argillaceous rocks of the Takashio-Tamada formations is characterized by the presence of detrital montmorillonite and authigenic clinoptilolite-mordenite-low-cristobalite. It indicates, therefore, that these argillaceous rocks have been subjected to temperatures between 56 and $69^{\circ} \mathrm{C}$ in the geologic past because the neoformation of authigenic analcite and low-quartz has not occurred as yet.

The total thickness of the TakashioTamada formations including the abovementioned mineral assemblage is about $\mathbf{5 8 0}$ $m$ (see Fig. 2). From the relation between the total thickness and the highest $\left(69^{\circ} \mathrm{C}\right)$ and the lowest $\left(56^{\circ} \mathrm{C}\right)$ paleogeothermal temperatures indicated for the mineral assemblage, the paleogeothermal gradient in the area is estimated to be about $2.2^{\circ} \mathrm{C} / 100 \mathrm{~m}$. The stratigraphic deficiency after the deposition of Tamada formation is calculated to be approximately $1800 \mathrm{~m}$ and thus the total thickness of the Miocene sediments in the area would be about $3800 \mathrm{~m}$. Here, the assumptions for this calculation are that the sediments before the deposition of Takashio formation were deposited continuously without subsequent erosion and that the average surface temperature in the area was $15^{\circ} \mathrm{C}$. Also, a rise of temperature due to the intrusion of volcanic rocks is not considered in the discussion.

\section{Organic Matter and Their Geo- chemigal Evaluation}

Usually, geochemical evaluation of petroleum source rocks considers the quantity and maturation of organic matter in the rocks (conversion to hydrocarbons) The latter consists of the coal petrophysical method based on the degree of alteration of kerogen from the standpoint of the kerogen theory of petroleum (Teichmüller, 1974; and Hood et al., 1975) and the geochemical method based on the CPI of normal alkanes, hydrocarbons/organic carbon ratio and 
compositional variation of naphthenic hydrocarbons (Tissot et al., 1971). In this paper, we will discuss the maturation of organic matter from the point of view of the hydrocarbons/organic carbon ratio $(\mathrm{HC})$ Corg ratio).

Yagishita (1962) compared the hydrocarbons in the Neogene argillaceous rocks of oil-producing and non-producing areas in Japan, studied the hydrocarbons in coals and oil shales, and suggested that more than 0.02 of the $\mathrm{HC} / \mathrm{Corg}$ ratio was the necessary condition for petroleum soruce rocks. Philippi (1965) studied the maturation of organic matter in relation to petroleum in the Los Angeles and Ventura basins and showed that the $\mathrm{HC} / \mathrm{Corg}$ ratio in the maturation zone in these basins was more than 0.02 and 0.025 , respectively. Tissot et al. (1971) studied the Cretaceous in the Paris basin and concluded that the $\mathrm{HC}_{\text {f }}$ Corg ratio in the maturation zone was more than 0.03. Recently, Asakawa (1975) investigated the maturation of source rocks in the oil fields of Japan and found that the average value of the HC/Corg ratio in the horizon where the CPI of normal alkanes approached 1 was 0.025 . From the above discussions, it is clear that the $\mathrm{HC} / \mathrm{Corg}$ ratio in the maturation zone is more than 0.02 .

We can also evaluate petroleum source rocks by the quantity of organic matter. In this case, 0.5 per cent is considered the minimum organic carbon content necessary, and generally more than 1.0 per cent is desirable for petroleum source rocks.

Hydrocarbon content (ppm), organic carbon content (per cent), and $\mathrm{HC} / \mathrm{Corg}$ ratio in argillaceous rocks of the area are plotted in the evaulation chart of source rocks (Fig. 4). The figure shows that the proportion of the rock with a HC/Corg ratio of more than 0.02 is very small.

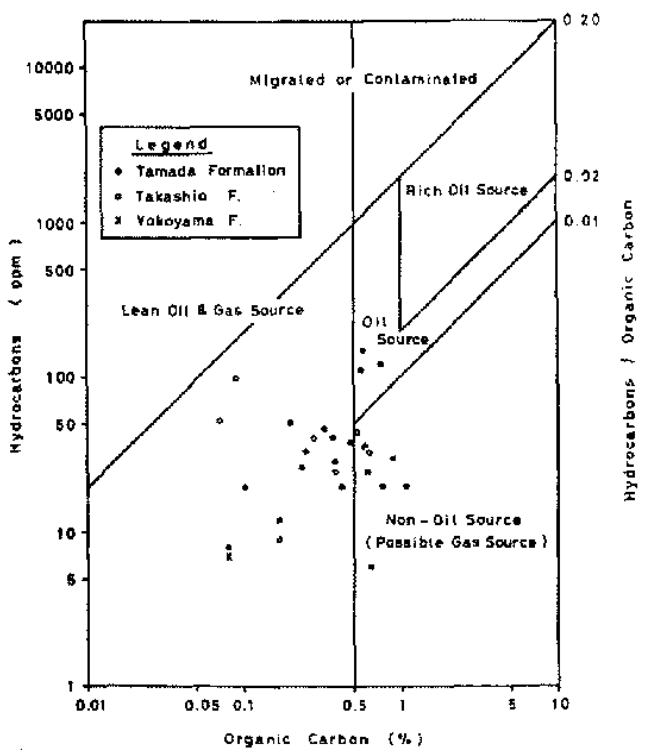

Fig. 4 Hydrocarbons (ppm), organic carbon con tent (per cent), and hydrocarbons/organic carbon ratio of argillaceous rocks in the studied area.

Though two samples of Takashio formation show very high $\mathrm{HC} / \mathrm{Corg}$ ratios, their organic carbon content is very low $(0.09$ and 0.07 per cent, respectively), which indicates reservoir rather than source rocks. Therefore, it is concluded that the maturation of organic matter to petroleum in the argillaceous rocks of the area has not progressed far enough.

As is shown in the evaluation chart, the rich oil source type is not found in the argillaceous rocks of the area, and the oil source type is present in some samples of the Tamada formation. Almost all of the other rocks belong to the non-oil source type (possible gas source type) or to the lean oil and gas source type. The above data suggest that the quantity of organic matter in the Miocene argillaccous rocks of the area is very low. 


\section{Discussion}

Oil and gas generated from kerogen under lower temperature will migrate primarily from argillaceous source rocks to porous reservoir rocks. Much water will be necessary as a carrier of these hydrocarbons, especially in the case of oil. Several investigators have considered that the expulsion of interlayer water from montmorillonite and montmorilloniteillite mixed-layer mineral by transformation during diagenesis would be most important as a carrier of oil (Powers, 1967; Burst, 1969; and Perry and Hower, 1972). Thus, their ideas should be called a late diagenetic migration theory (Taguchi, 1975).

Recently, Aoyagi and Asakawa (1977) studied in detail the expulsion mechanisms of interlayer and interstitial waters and the change of pores and grains in argillaceous sediments during each stage of diagenesis, and examined the depth and temperature of hydrocarbon generation in the various sedimentary basins in Japan and elsewhere. As a result, they reached a conclusion which should be called a middle diagenetic migration theory and is somewhat different from previous theories on primary migration of petroleum.

From this conclusion, they emphasized that the content and type of hydrocarbons generated during the middle stage of diagenesis (late compaction stage) would control the possibility of the occurrence of hydrocarbon pools in the sedimentary basin. For instance, in the Miocene sediments of Japanese oil fields, it is considered that primary migration of carrier water has occurred at the average burial depth between 1400 and $2800 \mathrm{~m}$ (Aoyagi and Asakawa, 1978) and the generation temperature oil has ranged between 100 and $150^{\circ} \mathrm{C}$ (Asakawa and Fujita, 1978). Therefore, the possim bility of formation of big oil pools will be high in areas where the paleogeothermal gradient is between 4.0 and $5.0^{\circ} \mathrm{C} / 100 \mathrm{~m}$.

Discussion on the possibility of hydrocarbon pools in the studied basin by the examination of paleogeothermal gradient and the vertical change of absolute porosity in argillaceous rocks is as follows. From the relation between the porosity of argillaceous rocks and depth at Fujioka GS-1 drilled in the southern part of Gunma Prefecture, as there are no deeply drilled wells in the studied area, it is considered that the burial depth during the late compaction stage, when the primary migration of carrier water would occur, ranges between 1100 and $2700 \mathrm{~m}$. In the studied area, the paleogeothermal gradient is estimated to be approximately $2.2^{\circ} \mathrm{C} / 100 \mathrm{~m}$ and the total thickness of the sediments after Miocene is calculated to be about $3800 \mathrm{~m}$, as described before. Therefore, the paleogeothermal temperature at 1100 and $2700 \mathrm{~m}$ in depth can be calculated as 39 and $74^{\circ} \mathrm{C}$, respectively. As is shown in Fig.

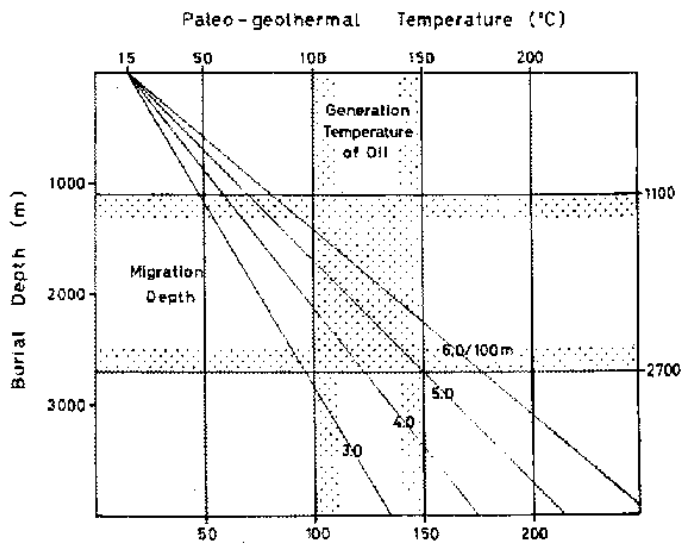

Fig. 5 Relationship between various palegeothermal gradients and generation temperature of oil in the Miocene argillaceous rocks of the area during the stage of primary migration. 
5 , the range of temperatures indicates that the generation of oil during the stage of primary migration has not progressed enough. This means that biochemical methane could has been generated at this temperature, but the generation of oil has not progressed much. These data are well supported by the maturity of organic matter as hydrocarbons determined by the abovementioned geochemical method.

It is considered, therefore, that the possibility of the occurrence of oil pools in the sediments during and after Miocene of the area is very low. However, the possibility of the occurrence of natural gas pools still remains, if there are proper reservoirs and traps for accumulation in the area. The possibility of the presence of oil pools may be high in the adjacent basins where the sediments are much thicker and the paleogeothermal gradient is much higher (more than $3.5^{\circ} \mathrm{C} / 100 \mathrm{~m}$ ).

\section{ConCLUSION}

The possibility of the presence of hydrocarbon pools in the sediments during and after Miocene southwest of Yaita City, Tochigi Prefecture, Japan, was considered from the theory of primary migration of carrier water of oil and also from the generation temperature of hydrocarbons in argillaceous rocks. For this discussion, it was necessary to calculate the paleogeothermal gradient and to determine the vertical change of absolute porosity of the argillaceous rocks in the area. The writers calculated the paleogeothermal gradient in the studied area from the mineral assemblage in the argillaceous rocks, though this calculation is generally made from the color of fossil pollen and also from the reflectance of vitrinite in coal or disseminat- ed humic matter.

Therefore, this may be a new method for the evaluation of oil prospecting areas which can be applied to basins where the paleogeothermal gradient has not been obtained as yet. In the future, we would like to utilize the method for the evaluation of sedimentary basins in prospecting new areas.

\section{AGKNOWLEDGeMENTS}

The writers express their sincere appreciation to Japan Petroleum Exploration Company for permission to publish this paper. Dr. S. Maiya of the same company and Dr. D.J. Lyons of Japan National Oil Corporation read the manuscript and gave us helpful suggestions and comments. Misses Toshie Takamasa and Sumi Kaneko of our laboratory drafted the figures. We thank them very much.

\section{REFERENCES}

Aoyagi, K., and T. Asakawa (1977) Primary migration of petroleum during diagenesis. Jour. Jap. Assoc. Petrol Tech., 42, 76-89 (in Japanese).

_._. and _._..... (1978) Primary migra tion theory of petroleum and its application to petroleum exploration. IAS Abstracts, Jerusalem, 1, 25-26.

- _. changes of clay minerals, zeolites and silica minerals during diagnesis. IAS Abstracts, Jerusalem, 1, 27-28.

- - Kobayashi, N., and T. Kazama, (1975) Clay mineral facies in argillaceous rocks of Japan and their scdimentary petrological meanings. Proceed. Internati. Clay Conf. Mexico City, 101-110, Appl. Publ. Ltd.

Asakawa, T. (1975) Relationships between normal alkanes and maturation of petroleum of oil fields in Japan. Jour. Jap. Assoc. Petrol. Tech., 40, 117-126 (in Japanese).

- and Y. Fujita (1978) Organic metamorphism and hydrocarbon generation in sedimentary basins of Japan. CCOP Tech. Publ. Ser. (in press).

Burst, J.F. (1969) Diagenesis of Gulf Coast clayey 
sediments and its possible relation to petroleum migration. Am. Assoc. Petrol, Geol. Bull., 53, 73-93.

Hood, A., Gutjahr, C.C.M., and R.L. Heacock (1975) Organic metamorphism and the generation of petroleum. Am. Assoc. Petrol. Geol. Bull. 59, 986-996.

Perry, E.A., and J. Hower (1972) Late stage dehydration in deeply burried pelitic sediments. Am. Assoc. Petrol. Geol. Bull., 56, 2013-2021.

Philippi, G.T. (1965) On the depth, time and mechanism of petroleum generation. Geochim. et Cosmochim. Acta, 29, 1021-1049.

Powers, M.C. (1967) Fluid-release mechanisms in compacting marine mudrocks and their importance in oil exploration. Am. Assoc. Petrol. Geol. Bull., 51, 1240m1254.

Taguchi, K. (1975) Trends in "late diagnetic theory of petroleum genesis"-a review. Jour. Jap.
Assoc. Petrol. Tech, 40, 8-23 (in Japanese). Teichmüller, M. (1974) Entstehung und Veränderung bituminöser Substanzen in Kohlen in Beziehung zur Entstehung und Unwaldlung des Erdöls. Fortschr. Geol. Rheinld. w. Westf., 24, 65-112.

Tissot, B., Califet-Debyser, Y., Deroo, G., and J,L. Oudin (1971) Origin and evolution of hydrocarbons in early Toarcian shales, Paris Basin. France. Am. Assoc. Pelvol. Geol. Bull, 55, $2177-2193$.

Lchio, T. (1950) Tertiary fossil fauna from Tochigi Prefecture. Jour. Geol. Soc. Jap., 56, 455-458 (in Japanese).

Yagishita, H. (1962) Distribution of hydrocarbons in Neogene sedimentary rocks of Niigata as a clue to the recognition of petroleum source rock. Jour. Jap. Assoc. Petrol. Tech., 27, 265296 (in Japanese).

\section{栃木県矢板市西南方地域の中新綍泥質岩の堆積鉱物学的 および有機地球化学的研究}

青柳 宏一，工藤 俀治，浅川 忠

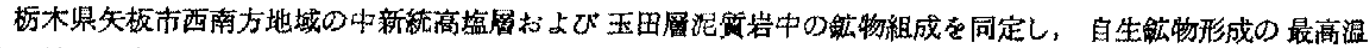



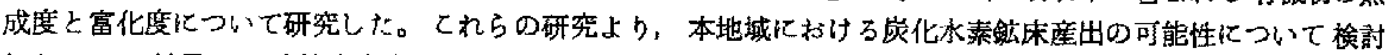

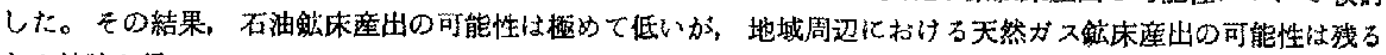
との結論を得た。 